\title{
Plantolie as dieselbrandstof: (i) Stabiliteitstoetse en spesifikasies vir verskillende grade plantolies
}

Aanvanklike korttermyn proefnemings met plantolie as dieselbrandstof deur die Nasionale Meganiese Navorsingsinstituut (WNNR) is deur langtermynstudies by die Afdeling Landbouingenieurswese (Departement Landbou) opgevolg. Die Nasionale Voedselnavorsingsinstituut is genader om hulp t.o.v. die chemiese samestelling en stabiliteitseienskappe van die plantolies te verleen. Om uitvoering aan hierdie versoek te gee is drie grade naamlik ru-, ontgomde en verfynde sonneblom- en soja-olie bestudeer. As basis vir die ondersoek is die Suid-Afrikaanse Buro vir Standaarde se spesifikasies vir eetbare plantolie (verfynde graad) gebruik en vergelykings met die ooreenstemmende spesifikasies vir dieselbrandstof is gemaak.

Plantolies se oorsprong word bepaal op grond van hulle identiteitskenmerke, terwyl die suiwerheidsgraad en algemene oksidasietoestand van die olies volgens die kwaliteitskenmerke beoordeel word. Die opbergingstabiliteit van die verskillende grade is bepaal deur 'n versnelde opbergingsondersoek, waarmee die induksieperiodes vasgestel is. Vryvetsuurwaardes, peroksiedgetalle en viskositeitsveranderings is tydens die versnelde opberging gemeet.

Op grond van die kwaliteitskenmerke van die plantolies wat ontleed is, kan verfynde sonneblomolie en soja-olie albei binne die dieselbrandstofspesifikasie geplaas word. Die fosfolipied-, as- en vry vetsuurinhoud van albei is laag en albei $k$ walifiseer dus op grond van suiwerheid. Die ontgomde olies is nie van dieselfde suiwerheidsgraad nie en val net buite die dieselspesifikasies. Die ru-plantolies val op grond van hulle onsuiwerheid totaal buite die dieselspesifikasies en word veral vanweë die onopgeloste fosfolipiede (gomme) as ongeskik beskou.

Die opbergingstabiliteit van die verskillende plantolies verskil aansienlik en hulle kan as volg in volgorde van dalende stabiliteit geplaas word: ru-soja-olie $>>$ ontgomde soja $>$ verfynde soja $=$ verfynde sonneblom $>$ ontgomde sonneblom = ru-sonneblom.

Indien die plantolies met dieselbrandstof vermeng word, vind ' $n$ herrangskikking in die stabiliteitsvolgorde plaas en die volgorde van dalende stabiliteit sien dan as volg daar uit:

ru-soja > ru-sonneblom > ontgomde soja > ontgomde sonneblom $>>$ verfynde soja $>$ verfynde sonneblom.

Dit is opvallend dat die ontgomde grade in mengsels met dieselbrandstof aansienlik gunstiger opbergingstabiliteit as die verfynde grade getoon het en dit sou dus voordelig wees om ook die ontgomde grade as dieselbrandstowwe te oorweeg. 'n Goed gefiltreerde ontgomde graad sonneblom- of soja-olie sal heel waarskynlik dieselfde brandstofresultate as die verfynde grade lewer en kan dus ook vir enjintoetse ingesluit word.

\section{L.M. DU PLESSIS}

N Voed N I, Scientia, Pretoria. April 1982. 